\title{
The Establishment Of Village Business Enterprise Based on UU No.6 / 2014 About Village
}

\author{
Amiek Soemarmi ${ }^{1}$, Etty Susilowati ${ }^{2}$, Siti Mahmudah $^{3}$ \\ \{amiek_hk@yahoo.com\} \\ Faculty of Law, University of Diponegoro
}

\begin{abstract}
The government's commitment to establish a Village Business Enterprise (BUMDes) is legally regulated in Law No. 6/2014 on Village. The establishment of BUMDes is derived from the results of village meeting which are agreed to be a Village Regulation. Various definitions of village in Indonesia lead to several problems in the process of establishing BUMDes. The research in normative juridical approach method through primary and secondary data is expected to obtain the result of development and regulatory problem concerning on BUMDes establishment process. The implementation of Law No. 6/2014 on Village has brought a new hope to the village community in general. Villages that haven't been, so far,fully paid attention to, with the issuance of the Village Law, villages will soon be elevated to a better order to the prosperity as the advance of cities, since villages are authorized to arrange and manage village wealth through the establishment of BUMDes, as set forth in Article 1 point 6 the Law No.6/2014 on Village. The establishment of BUMDes is a manifestation of the village's productive economic management that is carried out cooperatively, participative, emancipative, transparently, accountably, sustainably. The Indonesia territories are largely rural areas; hence, the above conditions are reflected in the lives of the village community. Village has grown in such a way that it needs to be protected, and empowered to progress in all areas, so that the present village objectives can be achieved to be strong, independent and democratic.
\end{abstract}

Keywords: BUMDes, Village, Village Regulation

\section{Introduction}

The establishment of BUMDes is a manifestation of the village's productive economic management that is carried out cooperatively, participative, emancipative, transparently, accountably, sustainably, The existence of BUMDes is established by the Village Government to utilize all potential economic, institutional, economic, and other potentials owned by the village, Given that initially BUMDes is a village finance institution managed by the community; it is expected to strengthen villages in the economic sector. Therefore, the different treatments will be in the form of Village Empowerment Institutions that participate in BUMDes. As a result, the community will instinctively establish their own community groups which have different characteristics leading to differences in the form of business in BUMDes. These differences likely become the inhibiting factors since before the implementation of Law No. 6/2014, there are already village business units in various forms of business, such as cooperation, association, etc. Dealing with this situation, this research will examine the establishment of BUMDes through identification of BUMDes establishment process and its 
management as well as obstacles faced in realizing the purpose of the establishment of BUMDes as stipulated in Law No. 6/2014 on Village.

One of the strengths of the village in Law No. 6/2014 on Village is the commitment of the state to recognize and protect the villages to implement the Article $18 \mathrm{~B}$ of the 1945 Constitution. The villages are not only legally recognized by the state but are also provided with a guaranteed source of income that comes from State and Regional Budgets and the original income from the village itself.

Indonesia is an archipelago country where two-thirds of its territory is water, which most of the citizens have livelihoods in traditional agriculture and fisheries seen from the cooperation in various aspects of life. Therefore, this research asks:

1. How is BUMDes establishment conducted in Indonesian village?

2. What problems arise in the establishment of BUMDes?

\section{Research Methodology}

The approach method used in the study is normative juridical approach,which is conducted by collecting data through literature research. Meanwhile, the data used are secondary data which are generally tangible documents, both legal documents and other documents. Normative juridical approach is used in the effort to achieve the validity of data with reference to legal norms set forth in legislation and judgment.

The research specification used in this research is Analytical Descriptive which tries to give a comprehensive, systematic, and depth overview of a situation or symptom examined; besides it expresses legislation related to legal theories that become object of research.

\section{Discussion}

\subsection{Definition of Village}

Village is a social institution that has a very important position. Village is an autonomous social institution with its own traditions, customs and relatively independent laws. Among others, this is indicated in the high level of diversity that village may be the most concrete manifestation of a nation.

According to Article 1 paragraph (1) of Law No. 6/2014 on Village:

"Villageis a village and indigenous villages or called by other names, hereinafter referred to as villages, is a unity of law communities with territorial boundaries authorized to regulate and administer government affairs, the interests of local communities based on community initiatives, origins, and/or a tradition that is recognized and respected within the system of the Government of the Republic of Indonesia."

Based on Article 19 of Law No. 6/014 on Village, Villages have the following authorities, namely:

a. carrying out the existing governmental affairs based on the rights of village origin.

b. carrying out governmental affairs that become the authority of the regency/municipality that is handed over to the village, i.e. the governmental affairs that can directly improve the community service. 
c. carrying out co-administration of the Government, Provincial Government and Regency/City Government.

d. carrying out other governmental affairs in which the legislation passed on to the village.

Article 25 of the Law No. 6/2014 on Village states that the Village Government is the Village Head or called by another name and which is assisted by village apparatus or called by another name.The diversity of characteristics and types of village, or called by another name, is not an obstacle for the founding fathersto impose his choice on a unitary state. It is recognized that in a unitary state there should be homogeneity, however, the Unitary State of the Republic of Indonesia continues to provide recognition and assurance of the unity of the legal community and the unity of indigenous and tribal peoples with their traditional rights [1].

In relation to the composition and implementation of the Regional Government, after the amendment of the 1945 Constitution, the arrangement of the Village or called in another name cannot be clearly found in the 1945 Constitution. What is regulated in the 1945 Constitution is precisely the unity of indigenous peoples along with their traditional rights, as written in Article 18B paragraph (2). General Elucidation of Law No. 6/2014 stipulates that the Village arrangement or referred to by another name in terms of its government refers to the provisions of Article 18 paragraph (7) which affirms that "The structure and procedure of the implementation of Regional Government is regulated in Law." It means that the arrangement of the Village is integrated into the regional government structure within the Indonesian government system [2]

\subsection{Establishment Of BUMDes}

In Indonesia, which mostly consists of fisheries and agriculture, the existence of BUM Desa is established by the Village Government to utilize all potential economic, institutional, and other potentials owned by the village. It is particularly in increasing the income sources of rural communities, dealing directly with agriculture, creative economic products; meanwhile the northern regions are largely populated by fishermen. The purpose of BUM Desa can perform the functions of agricultural services, fisheries, trade, and other economic development.

Currently in most of the villages in Indonesia, the village economic institution as a credit institution that has been operating is Rural Credit Board (Badan Kredit Desa (BKD)) which runs its mission in accordance with the objectives of the village's Credit Institution. BKD products include savings and loan products in which its members are those listed on the institution. As a Rural Credit Board, its business form is non-legal entity such as Firm or CV. It merely provides very limited benefits of the fulfillment of its members for personal interests. In other words, it has not been able to provide benefits to participate in building the village [3]

The establishment of Village Owned Enterprises (hereinafter referred to as BUMDes) aims to be locomotives for local economic development at the village level. The local economic development of the village is based on the needs, potential, village capacity, and equity participation of the village government in the form of village financing and wealth with the ultimate aim of increasing the economic level of rural communities. The establishment of BUMDes as a locomotive of development in the village is more motivated on the initiative of the government and the village community based on the cooperative, participative, and emancipative principles of the village community. 
The establishment of BUMDes is agreed through the Village Meeting. It is regulated by Village Regulation [4] The organization managing BUMDes should be separated from the village government organizations. At least, this organization consists of advisory and operational executives.Advisor chaired ex officio by the Village Head. Meanwhile, the operational executive is an individual who is appointed and dismissed by the Village Head. Operational implementation is prohibited to be occupied by individual which is concurrently occupying positions that carry out the function of the implementation of village government institutions and village social institutions [5]

Government, provincial government, district/city government and village governments encourage the development of BUMDes by [6]:

a. providing grants and/or access to capital;

b. providing technical assistance and access to markets; and

c. preserving BUMDes in natural resource managementin the village.

In the framework of inter-village cooperation, 2 (two) villages or more can establish joint BUMDes. It can be done through the establishment, merger, or smelting of BUMDes. The establishment, incorporation or merger of BUMDes and the management of the BUMDes shall be carried out in accordance with the provisions of the law. Further provisions regarding the establishment, management and management and dissolution of BUMDes shall be regulated by a Ministerial Regulation [7]

\subsection{Problems Faced In The Establishment Of BUMDes}

In the process of establishing BUMDes, it cannot be separated from the problems/obstacles encountered:

The first problems faced in the process of establishing BUMDes is the lack of good communication between the village government, BUMDes officials and the village community. Therefore, there are still many villagers who do not know clearly about the programs of BUMDes.

\section{Closing}

In Indonesia, which mostly consists of fisheries and agriculture regions, the existence of BUM Desa is established by the Village Government to utilize all potential economic, institutional, and other potentials owned by the village; particularly in increasing the income sources of rural communities, which deal directly with agriculture, creative economic products, while the northern regions are largely populated as fishermen. BUM Desa is expected to be able to perform the functions of agricultural services, fisheries, trade, and other economic developments, because BUM Desa is an institution managed separately with Village Government. As a result, many obstacles arise in the management of BUM Desa especially in the process of establishment through village meetings and decided in Village Regulations which is in accordance with the Law No. 6/2014 on Village.

Acknowledgments. The authors would like to express the great gratitude to the Faculty of Law, University of Diponegoro which has provided financial support in research on the Establishment of Village Owned Enterprises and the problems faced based on the 
Establishment through the Law No. 6/2014 on Village which is a new regulation for the development of constitutional law in Indonesia.

\section{References}

[1] Awang Azam, Implementasi Pemberdayaan Desa, (Pustaka Pelajar: Yogyakarta: 2010).

[2] Etty Susilowati, 2014, Research Result: Perlindungan Hukum Bagi Nasabah Badan Kredit Desa.

[3] Huda Ni'matul, Hukum Pemerintahan Desa, (Setara Pres: Malang, 2015)

[4] The 1945 Constitution of the State of the Republic of Indonesia

[5] The Law No. 6/2014 on Village

[6] The Government Regulation No. 43/2014 on the Implementation of Village

[7] The Minister of Village Regulation No. 4/2015 on Establishment, Arrangement, Management and Dissolution of Village Owned Enterprises. 